was given in a lecture by Prof. Carl Voegtlin to the Washington Academy of Sciences, and published in the Journal of the Academy for October 4. After directing attention to such diseases as scurvy and beri-beri, due to deficiency in certain constituents of food, Prof. Voegtlin discussed the chemical nature of "vitamines." They are somewhat readily destroyed by temperatures above $100^{\circ} \mathrm{C}$, , especially in alkaline reaction. The acidity of lime-juice thus preserves the anti-scorbutic properties of the fresh fruit. They are removed from solution by adsorption on the surfaces of various inert powders, such as kaolin, charcoal, and mastic, a property which will probably be of value in obtaining them in a concentrated form. The lecturer makes a slip, however, when he states that it is necessary that a substance should be in the colloidal state in order that it may be adsorbed. It is merely necessary that its deposition shall reduce the surface energy of the adsorbent; amyl alcohol, for example, is largely adsorbed by powders. According to McCollum there are two kinds of accessory factors which it is necessary to add to polished rice in order to make it effective for growth, neither being sufficient alone. One of these is contained in butter, the other in wheat germ; this latter appears to be insoluble in fat, although soluble in alcohol and in water.

Vitamines are not manufactured by the animal organism, but they do not readily disappear from it when once supplied. It seems that they do not suffer loss by chemical change. This fact suggests that their action is of a catalytic nature, somewhat like that of traces of zinc in the growth of Aspergillus, shown by Raulin. Or they may be related to the hormones of internal secretion.

The remainder of the address is devoted to the consideration of the relative content of various foodstuffs in these substances. It is pointed out that ordinary mixed diets contain a liberal supply, but that tinned foods may be deficient. An exclusive diet of highly prepared cereals, such as polished rice, is dangerous. Owing to the value of fresh vegetables in this respect, we may note the importance of not restricting the import of such fruit as oranges, which are apt to be the only vegetable consumed in the poorer districts of London.

It appears that, although phosphorus is not known to be a constituent of vitamines, yet a fairly accurate index of the vitamine content of cereals may be given by their phosphorus content. With regard to bread, attention is directed to the use of sodium bicarbonate in its manufacture. This is converted on baking into the carbonate, and the resulting alkalinity tends to destroy the vitamines. If acid substances, such as butter-milk or cream of tartar, are also added, the effect is obviated.

Owing to the small quantities of these essential factors which are present in foods, the difficulty of investigation is great. But the problem is being attacked by many workers and valuable results are being obtained.

No. 2463 , VOL. 98$]$

W. M. Bayliss.

\section{SIR E. B. TYLOR, F.R.S.}

$A$ FTER a period of twilight of seven or eight A years and a few days' illness, Emeritus Prof. Sir E. B. Tylor peacefully passed away on the night of January 2, and with his death closes a memorable chapter in the history of anthropology in England.

Edward Burnett Tylor was born at Camberwell on October 2, $183_{2}$, and was educated at Grove House School, Tottenham, belonging to the Society of Friends. At an early age he entered his father's business, but his health soon broke down, and he travelled abroad for several years. In 1856 he visited Mexico in company with the ethnologist, Henry Christy, who doubtless stimulated his interest in ethnology. The observations made during this tour were published in his first book, "Anahuac; or, Mexico and the Mexicans" (186r). Thenceforth he led the strenuous, uneventful life of a student. In $185^{8}$ he married Miss Anna Fox, of Wellington, with which town he was closely associated until the day of his death.

Tylor never had a university training, but several universities honoured themselves by conferring on him an honorary degree. For many years he was keeper of the University Museum at Oxford, and he took great delight in and did much to improve the Pitt Rivers Museum. He was reader in anthropology in the University of Oxford from 1884 to $x 895$, when a professorship of anthropology was instituted for him; he became emeritus professor at the close of 1909. The Royal Society elected him to a fellowship in $187 \mathrm{r}$. $\mathrm{He}$ had the distinction of being invited to be the first lecturer under the Gifford Trust at Aberdeen, but his lectures, given in $r 889-91$, have, unfortunately, never been published. The honour of knighthood was conferred on him in I9I2. Many other distinctions by learned societies marked the high appreciation in which he was universally held. Tylor was a tall man of imposing appearance, and his friendly, modest courtesy will never be forgotten by those who had the privilege of knowing him.

The publication of his masterly work, "Researches into the Early History of Mankind and the Development of Civilization" (1865), at once brought Tylor to the forefront as an ethnologist. In some respects it was pioneer work, as in it he assembled multitudinous facts culled from $a$, wide range of reading, and so grouped them as to bring out new conclusions. His reputation as a thinker and as an exponent of "ye beastlie devices of ye heathen" was further enhanced by the publication in $187 \mathbf{r}$ of "Primitive Culture: Researches into the Development of Mythology, Philosophy, Religion, Language, Art, and Custom" (2 vols.). His great erudition was presented with such a charming literary style and flashes of quiet humour that the book was read with delight by people of very varied interests. It sperdily became a "classic," and such it will always remain. As Andrew Lang said in the "Anthropological Essays presented 
to Edward Burnett Tylor in honour of his $75^{\text {th }}$ Birthday, October 2, 1907": "The extent of his reading, his critical acumen, his accuracy, his power of exposition, his open mind, and his scientific caution make this book no passing essay, but a possession for ever."

Ten years later Tylor published a most excellent little book, "Anthropology: an Introduction to the Study of Man and Civilization" (I88I), which still remains a valuable and suggestive guide for those who desire to know the significance of what Max Müller termed "Mr. Tylor's science."

On looking through the compendious bibliography of Tylor from $186 x$ to 1907 compiled by Miss Freire-Marreco for the above-mentioned Essays, it is obvious that, apart from his four books, his activity largely manifested itself in lectures, reviews, and addresses. His papers, even when descriptive, were always marked by a breadth of view and an endeavour to drive home the lessons to be garnered from the facts. The most important of these papers is that "On a Method of Investigating the Development of Institutions, applied to Laws of Marriage and Descent," in which it was his "aim to show that the development of institutions may be investigated on a basis of tabulation and classification." In order to indicate the wide range of his studies, the following are some of the subjects of his papers: Games, Australian marriage laws, the origin of the plough and wheel-carriage, the Asiatic relations of Polynesian culture, the winged figures of the Assyrian and other ancient monuments, charms and amulets, the Tasmanians as representatives of Palæolithic man, and totemism. Indeed, there were few aspects of anthropology which he had not investigated, and he enriched all those with which he dealt.

Although Tylor illustrated his theses with a wealth of references, he never permitted himself to be swamped by them. He will always be regarded as the first and foremost exponent of the comparative method in this country, and though, as was natural for a contemporary of Darwin and Huxley, he was imbued with the principle of development, yet he was fully alive to the borrowing of culture and to cultural drifts ; thus, ever since $x 874$ he repeatedly drew attention to the direct cultural influence of Asia on the higher civilisations of the New World and the spread thence of certain elements of that culture among more barbarous tribes. Tylor was always interested in method, and it was mainly by his efforts in this direction that ethnology can now claim to be a science.

A. C. HADDON.

\section{CAPT. F. C. SELOUS.}

THE late Capt. Frederick Courteney Selous, whose death in action against the remaining German forces in East Africa has just come as a painful shock to his many friends in the two hemispheres, was born in London on the last day of r85 $\mathrm{r}$. His surname-pronounced in the French manner-indicated his French ancestry on the No. 2463 , VOL. 98$]$ father's side, but his main composition was English and Scottish, and his appearance almost Scandinavian in his blondness and his Nordic violet eyes-perhaps the most striking feature in a very charming face. As a young man he was exceedingly good-looking, and always reminded me--after I had been to South Africa-of a not uncommon type of Boer (which, indeed, is a very common type in Holland), similarly blond and with the like violet-grey eyes. I first met him in the early 'eighties at the house of his near relatives, the Garrods, of Harley Street. The great comparative anatomist, Alfred Garrod, was his cousin, and similarly of Huguenot-French origin.

Selous was educated first at Rugby and afterwards in French Switzerland and in Rhenish Germany, so that he entered on his African explorations with a well-filled mind and a trained power of observation. I rather fancy his decided bent for natural history and the pursuit of big game must have arisen from his Garrod connections and the consequent deep interest he took in the Zoological Gardens (Prof. Garrod was prosector there).

He was an African pioneer of the very best type. Always a total abstainer, there was never anything rowdy about him, yet he won the respect and frank liking of the roughest types of men of all races. He was greatly esteemed in the United States. Only three days before the announcement of his death I received a note from the secretary of the New York Zoological Society, recounting a talk with Prof. H. F. Osborn and Colonel Roosevelt about the war, winding up with the question: "Have you any news about Selous? We are all so anxious about him."

Selous was not a systematist in zoology, but he was a close and accurate observer of the lifehabits of birds and beasts, and in his branch of natural history he contributed much valuable lore to science. If all his contributions were removed from the galleries and drawers of the British Museum, our examples of the African faunaespecially its spectacular fauna-would indeed be poor. Moreover, he added very greatly to our knowledge of birds' eggs, especially the eggs and nests of Palæarctic (and Mediterranean) birds.

His loss will be a source of grief to many, not only here and in the United States, but also in Africa. I should think he was one of those few notable and active men who never made an enemy, not even when he took a strong, almost vehement, line in the matter of the protection of birds from the ravages of the plumage trade, on which subject he made terse and most effective speeches.

H. H. Johnston.

\section{NOTES.}

THE question of closer co-ordination between scientific research and practical design in aeronautics has been mentioned more than once in these columns, and it now appears that such co-ordination will be one of the good results following the reorganisation of the Air Board. The inclusion of two representatives of the Ministry of Munitions and of a technical director 